Ана М. Јањушевић Оливери ${ }^{1}$

Универзитет у Приштини

са привременим седиштем

у Косовској Митровици

Филозофски факултет

Катедра за српски језик и књижевност

https://doi.org/10.18485/ai_fonefonosj.2020.ch10

811.163.41'271.16(497.16)

\title{
ПСЕУДОРЕФЛЕКСИ ЈАТА У ЈЕЗИКУ ПИСАЦА ИЗ ЦРНЕ ГОРЕ
}

Предмет овог рада јесу ријечи и облици ријечи у којима се умјесто етимолошког $u$, односно $e$ јавља секвенца $(u)$ је која се не може посматрати као рефлекс jата. Истраживање се спроводи на корпусу ексцерпираном из прозних дјела црногорских писаца који су стварали крајем деветнаестог и током двадесетог вијека. Као контролни корпус, који би требало да покаже савремени статус забиљежених псеудоијекавизама, послужиће електронско издање црногорског дневног листа Вијести.

Кључне ријечи: псеудорефлекс, вокал јат, је-рефлекс, ије-рефлекс, коријен, суфикс.

0. Појава коју разматрамо у овом раду различито је именована у домаћој науци о језику. Најчешће се означава као хиперијекавизам или хиперјекавизам (Путанец 1963). Овима је сличан термин суперјекавизам, којим се користи А. Пецо, уз објашњење да су у питању „случајеви у којима се јављају ије или је, иако ту није

1 anna.janjusevic@gmail.com 
било ғ" (Пецо 1967: 93). Наведени термини нису сасвим адекватни, јер самим називом упућују на један од рефлекса јата (ије или је), а уз то нису ни једнозначни. Они се, наиме, могу односити и на случајеве у којима се јавља ије или је умјесто неког другог рефелкса јата (на примјер, ије умјесто је: засиједати - засједати, или је умјесто и: хтјео - хтио). Осим ових, у оптицају су и термини псеудојатизам (Шипка 2010) и псеудорефлекси јата (Маројевић 2005), односно секундарни рефблекси јата (Путанец 1963). Дајемо предност потоњим двама терминима, јер најјасније упућују на појаву о којој је ријеч, тј. на лажне рефлексе, односно на секундарно развијање рефлекса̂ јата у позицијама у којима се никада није употребљавао овај прасловенски вокал.

Истраживање смо ограничили на употребу псеудорефлекса̂ јата у језику писаца из Црне Горе, а грађу смо ексцерпирали из прозних дјела насталих крајем деветнаестог и током двадесетог вијека. Циљ истраживања јесте да испита заступљеност ненормативних облика, те разлоге њихове појаве, али и да утврди савремено стање када су у питању ријечи и облици ријечи са секундарним рефлексом, те ће нам као контролни корпус послужити електронско издање црногорског дневног листа Вијести.

У раду нећемо разматрати ријечи које су прихваћене као нормативне у ијекавском стандарду (на примјер, замјеничке прилоге овдје, ондје и др. у којима се секундарно развио рефлекс је у склопу партикуле де), већ само оне случајеве који не припадају норми, или пак оне у вези са којима се норма колеба. Нећемо се бавити ни већ описаним лексемама са псеудорефлексима јата, ${ }^{1}$ какве су: льеш, отмјен, вјересија, осјека, къегиға,

1 В. Путанец 1963. и Шипка 2010. 
ијелулит, ијелулоза, тестијер, ипанцијер - јер за њих нисмо нашли потврду у језику црногорских писаца.

Већина секундарних рефлекса јата које анализирамо у овом раду посвједочена је у народним говорима у Црној Гори, а неке ријечи и облици ријечи се и први пут овдје помињу као псеудо(и)јекавизми. Грађу ћемо разврстати на основу односа секундарног рефлекса јата и вокала чије мјесто заузима, а као поткритеријум ће се увести и поријекло лексике.

1. Ије умјесто етимолошког $e$

1.1. Псеудорефлекс ије умјесто етимолошког $e$ јавља се чешће у домаћим него у страним ријечима.

1.1.1. Умјесто етимолошког дугог е развио се секундарни рефлекс јата код именица болест и голет, те их у корпусу, поред неупоредиво чешћих и уобичајених облика са $e$ (примјери 16), налазимо и у ликовима болијест и голијет (1a).

(1a) Болијест се оте [...] (Лопичић: 73); [...] да због њене болијести не робује имање (Исто: 75); Знала је да је прошлу годину оставио лозу у болијест (Исто: 204) [...] знаш што је болијест (Исто: 428);

Под њима $[\ldots]$ села невидљива и чије се постојање може само наслутити по оним пространим голијетима (Лалић, ПС: 133);

(16) Ту болест ти баштиниш (Трипковић, Извиријеч: $235) ;[\ldots]$ дјеца болест нагрћу на себе (Вуковић: 65); [...] вардај да ти болест на зној изађе (Лалић, ПС: 97);

[...] њене обличасте травне голети више од ичега радовале његове очи (Ђилас: 23).

Лик болијест је посвједочен само код Н. Лопичића, док други писци чија смо дјела прегледали употребљавају регуларни облик болест. Како тврди М. Стевановић (1953: 116), ријеч болијест се јавља и у Љубишином и Његошевом језику, а забиљежио ју је и В. Караџић 
у Црној Гори. Премда Стевановић напомиње да се у народним говорима ријеч болијест ријетко јавља, њу ипак биљеже дијалектолошке студије, како на територији староштокавских (Црмница - в. Милетић 1940: 253. и Паштровићи - в. Јовановић 2005а: 116-117), тако и на територији новоштокавских говора (источна Херцеговина - Вушовић 1927: 10). И у рјечнику ЈАЗУ даје се податак да се у „јужном говору”, када је у питању ова лексема, среће ије умјесто $e$, уз објашњење да је у питању рефлекс јата које се ту секундарно развило од дугог $e$ (РјЈАЗУ, дио 1: 528). Према нашем мишљењу, на појаву овог псеудоијекавизма утицали су глаголи (о)болети и оболијевати, изведени од истог коријена суфиксима који садрже вокал јат.

С друге стране, изненађује чињеница да је именица голијет забиљежена у Лалићевом језику, када се зна да су о језику издањаิ овог писца помно бринули лектори. Међутим, ни овај лик није непознат народним говорима - биљежи га нпр. Вушовић (1927: 10) у источној Херцеговини, али и Ђуровић (1980: 282) у говорима околине Прибоја.

1.1.2. На мјесту дугог $e$ јавља се секвенца ије и код глагола крештати, који је потврђен код два писца у лику кријештати:

(2) [...] једна је већ двапут закријештала из трулине (Н. Ковачевић, Извиријеч: 167); [...] глас кријешти као у вране (Вуковић: 28).

Описи народних говора у Црној Гори не пружају информације о овом лику. Псеудоијекавизам кријештати вјероватно се развио под утицајем псеудорефлекса одомаћеног у народним говорима код ономатопејског глагола сличне семантике - кукуријекати.

1.1.3. У једном случају је забиљежен псеудорефлекс uje умјесто кратког $e$. У питању је придјев-интензи- 
фикатор боговетан, познат у неким говорима у лику боговјетан (в. у језерско-шаранском говору - Остојић 2003: 266). Код Команина биљежимо регуларни лик боговетан, док у језику Луке Јововића, приповједача са краја XIX и почетка XX вијека, ова ријеч садржи секвенцу ије:

(3а) Да имају сваки боговијетни дан да се хране (Јововић, Извиријеч: 129);

(36) Цио сам је боговетни дан молио да ме пусти с њом (Команин: 84).

У литератури се расправљало о придјеву истоветан који има слично образовање. ${ }^{2}$ За овај потоњи придјев се у Правопису каже да је „обичније истовјетан него истоветан, мада јат није изворно" (Правопис 2014: 28). Сматра се да се код придјева истоветан, цигловетан, драговетан развио секундарни рефлекс јата под утицајем придјева разговијетан (Путанец 1963: 76). На исти начин можемо тумачити и секвенцу ије у придјеву боговијетан.

1.2. Псеудорефлекс ије развија се умјесто изворног $e$ и у ријечима страног поријекла. На примјер, у дјелу Жарка Команина, умјесто регуларног подумента, насталог од латинског fundamentum, регистрован је искључиво лик подумијента:

(4) Никша узме главу и узида је у подумијенту (Команин: 36); Павле Богдановић прича да се она „глава која збори“ $[. .$.$] откинула из подумијенте (Исто: 37); [...]$ почео је да удара подумијенту за нови зид (Исто: 116).

Лик са псеудорефлексом је могао доспјети у језик овог писца под утицајем народних говора, у којима се биљежи латинизам подумијента (в. Вушовић 1927: 10. и Пешикан 1965: 106).

2 Опсежне податке о томе даје М. Шипка (2010: 174-177). 
1.3. Да су ликови болијест, голијет, кријештати и подумијента заиста одлика народних говора и да, као такви, нису могли поколебати стандард, свједочи и чињеница да се не појављују у језику актуелне дневне штампе у Црној Гори. У дневнику Вијести забиљежени су само облици болест, голет и крештати. Потврду за латинизам подумента нисмо нашли, пошто га је, по свој прилици, истиснула домаћа ријеч темељь.

Придјев боговетан, будући да је маркиран експресивношћу, одлика је разговорног и књижевноумјетничког стила, те портал Вијести не пружа потврду за његову употребу. Међутим, нашли смо више примјера за придјев истоветан, који има слично образовање, а јавља се искључиво као псеудојекавизам истовјетан, што је у сагласности са наведеном напоменом из Правописа:

(5) [...] istovjetan nagradni fond kao prošle sezone (Вијести, 11. VII 2019); „Čekićari” poveli golčinom Pedra Obijanga, izjednačio Heung-Min Son na istovjetan način (Вијести, 4. I 2018); Sa strane državnih organa Crne Gore ne bi trebalo odgovarati na ovakve mjere na istovjetan način [...] (Вијести, 2. VI 2017).

\section{2. Псеудорефлекс је умјесто $e$}

2.1. Псеудорефлекс је јавља се умјесто етимолошког кратког $е$. И ова појава се чешће среће у ријечима домаћег, словенског поријекла него у лексици преузетој из других језика, а посебно је захватила придјев кисео и лексему свештеник, као и ријечи изведене од њих.

2.1.1. У језику писаца из Црне Горе јављају се напоредо и псеудојекавизам кисјео (6а) и лик кисео (6б):

(6a) кисјео задах напуни ми уста (Лопичић: 83); док су остали [...] мезили кисјео купус и суво воће (Ђилас: 30 );

(66) још се осјећа киселккаст задах (Лалић ПС: 36 ); 
опекотину на лицу намазаћу ти киселим млијеком (Вуковић: 63).

Истраживачи народних говора биљеже искључиво форму са псеудорефлексом јата, и то са извршеним јекавским јотовањем дентала $c{ }^{3}$ Када је у питању придјев кисео и његове изведенице, ваља напоменути да поријекло суфикса -ел (>ео) није сасвим јасно, јер постоје индиције, ослоњене углавном на стање у нашим народним говорима, али и у неким другим словенским језицима, да је ту могло бити и јаm. ${ }^{4}$ Ипак, норма стандардног српског језика овај придјев прихвата само у облику кисео, тако да његову варијанту са секвенцом је сматрамо псеудојекавизмом.

2.1.2. Иако је е у ријечима свештеник, свештенство, освештати постало од прасловенског назалног вокала предњег реда, а не од вокала jam, у језику појединих писаца из Црне Горе долази до интерференције са основом свът-, па се поред нормативних (76), срећу и ликови ових ријечи са псеудорефлексом је (7a).

(7а) [...] опонашајући свјештеника [...] (Лопичић: 406); Овдје почива Илија Б. Рујановић, свјештеник богетићки и пелиновачки (Команин: 99); Глас из тмине памћења шапуће [...] да је свјештеник Благо завадио Рујаниће с Бездановићима (Исто: 188); Па свјештавасмо масла (Јововић, Извиријеч: 116).

(7б) [...] читали су свештеници (Лопичић: 441); [...] кад свештеници угасише свијеће [...] (Лопичић, 441); [...] ућутао се и свештеник (Ђилас: 75); Осуђеницима је било познато да је Мирко једини свештеник у граду (Билас: 217); [...] законодавце и свештенике - све Српство Зета дала је мила (Краљ Никола: 538); [...] ми

3 УП.: Вуковић 1938-1939: 17; Пешикан 1965: 106; Станић 1974: 75, Пижурица 1981: 70.

4 В. о томе у: РјJАЗУ 5: 8. 
смо они од Косова, што свећају и пјевају несреће српске (Ђилас: 57).

Сакупљени материјал показује да постоје колебања у погледу употребе регуларног облика са $e$ и оног са псеудорефлексом чак и у језику истог писца (у питању је Никола Лопичић). Дијалектолошке студије не биљеже ликове са секвенцом је. Изузетак у том погледу представљај опис говора околине Колашина у којима је посвједочен псеудорефлекс је у глаголу освјештати, док именица свештеник и придјев свештени имају само тај лик (Пижурица 1981: 71).

2.1.3. Псеудорефлекс јата јавља се умјесто кратког $e$ и у именици бољештина. Једини примјер ове врсте забиљежен је у приповијеци Луке Јововића. Код Чеда Вуковића и Милована Ђиласа, међутим, јавља се регуларни лик болештина, односно болешчина.

(8а) [...] немаше овијех болешиина [...] (Јововић, Извиријеч: 116);

(86) Ако ме каква болешчина свали с ногу [...] (Вуковић: 85); Али шта да тражи њен народ - [...] одавно већ без неписмених, без болемтина? (Ђилас: 84).

Претпостављамо да је узрок појаве овог псеудојекавизма интерференција са глаголом бољети изведеним од истог коријена помоћу суфикса који је садржао кратко jam. Ваља напоменути да у црногорским народним говорима није забиљежен лик бољешчина.

2.1.4. У Лалићевој збирци приповједака Први снијег забиљежен је сасвим необичан псеудојекавизам:

(9) Горе изнад куће има она усамљене савардаке с овсјеном сламом (Лалић ПС: 150).

Овај псеудојекавизам не помиње се ни у једној дијалектолошкој студији, нити у радовима који се дотичу феномена псеудојатизма. Псеудорефлекс је употријебљен у склопу суфикса -ени, којим се творе при- 
дјеви у чијој основи се налази (градивна) именица. Овај суфикс са секвенцом је умјесто $e$ јавља се и код градивног придјева вуюени, који смо чули у околини Никшића, али за који нисмо нашли потврде у грађи, нити у постојећим описима народних говора.

2.1.5. Псеудорефлекс је умјесто етимолошки оправданог е биљежимо и у творби придјева нетрпјељив, при чему је појава псеудојатизма захватила суфикс.

(10) Брат - окошт и хитар као хрт, нетрпјељив ('Илас: 184$)$.

Овај примјер је евидентиран у роману М. Ђиласа, у коме се и иначе примјећује несигурност у погледу коришћења ијекавског стандарда. До интерференције је : e и овдје је дошло под утицајем облика инфинитива mpnjemu.

2.1.6. Да је појава псеудорефлека̂ јата захватила не само коријене и суфиксе него и наставке за облик, свједочи глаголски прилог садашњи глагола видјетu, који ce, поред регуларног облика видећи (116), у језику црногорских писаца Н. Лопичића и М. Лалића јавља и у лику видјећи (11a):

(11a) [...] видјећu добро како је с другом (Лопичић: 205); Buдjeћu да огња нема [...] (Исто: 382); [...] видjeћu да нема друге (Исто: 443); [...] страшно се зачуди видјећи да су га овом приликом разминули (Лалић С: 148); [...] видјећu да то код њих не изазива онај утисак који је он замишљао (Исто: 148); видјећи да то није баш убједљиво додаде [...] (Исто: 177);

(116) [...] видећи да му је лик невјероватно снужден (Лопичић: 83); [...] видећи да им прича ништа не помаже (Исто: 207); Видећи је тако брижну (Исто: 335); [...] видећи батаљон развијен за напад (Ђилас: 77).

Преглед грађе показује да у језику Н. Лопичића постоје колебања између употребе псеудојекавизма и 
нормативног облика. Код Лалића је, међутим, прегледом двију књига, регистрован једино лик видјећu. Познато је да се глаголски прилог садашњи гради додавањем наставка -ћu на презент трећег лица множине, али овдје је, очигледно, посриједи интерференција са инфинитивом видјети.

2.2. И у лексици страног поријекла биљежимо употребу псеудојекавизма умјесто изворног $е$. У питању је глагол секирати (се) настао од италијанског seccare. Код Лалића је, међутим, евидентиран само у лику сјекираmu ce:

(12) Дотле се Перко није сјекирао [...] (Лалић ПС: 27); [...] око којих се није сјекирао (Исто: 54); [...] ништа се ти, жацо не сјекирај (Лалић С: 18).

Ова појава је широко захватила црногорске народне говоре, о чему свједоче и подаци у појединим њиховим описима (Јовановић 2005а: 117). Сама интерференција спада у домен тзв. народне етимологије, која је довела у везу поменути глагол и домаћу ријеч секира/сјекира.

2.3. Од наведених псеудојекавизама у језик црногорских медија, судећи према налазима затеченим на порталу Вијести, продрли су једино именица свјештеник и придјев кисјео, као и ријечи које припадају њиховим деривационим језгрима:

(13a) Preminuo svještenik koji je savjetovao Buša, Regana, Ajzenhauera; Sveštenik Bili Grejem [...] umro je danas u 100. godini (Вијести, 21. II 2018); Predsjednik Rusije Vladimir Putin nije želio da ga svještenik Ruske pravoslavne crkve poljubi u ruku (Вијести, 7. VIII 2012); Mitropolit Crnogorske pravoslavne crkve (CPC) Mihailo poručio je da je vrijeme da nakon dvije decenije svještenstvo i vjernici te crkve uđu u crnogorske hramove (Вијести, 5. V 2013);

(136) Prema tom sporazumu, Kimpanov - sveštenik Neofit, prihvatio je da bude osuđen na šest mjeseci zatvora, 
a tu kaznu će izdržavati u kućnim uslovima (Вијести, 21. IX 2019); Sveštenik je iz aviona sipao vodu na grad Tver, kako bi ga pročistio od alkoholizma i bludničenja (Вијести; 16. IX 2019); Okupljeni građani i sveštenstvo odbili su da se raziđu, bez obzira na pozive policije (Вијести, 3. IV 2019).

(14a) Kupus možete da ukisjelite i bez glomaznih kaca za svega dva do tri dana (Вијести, 2. II 2019); Među hranom koja je povučena sa tržišta su konzervirano povrće, kao što su turšija, kisjeli kupus i cvekla, ali i kobasice i drugi pekarski proizvodi (Вијести, 10. III 2012);

(146) Stara priča o ljubavi trudnica prema kiselim krastavcima nije mit nego stvarnost [...] (Вијести, 10. III 2018); Jelo se obično jede sa jednom švedskom vrstom hljeba (tunnbröd), a kreativci mu dodaju kuvani krompir, luk i kiselu pavlaku (Вијести, 16. IV 2011).

Прегледом портала Вијести установили смо да је репартиција облика кисјели/кисели равноправна, док нормативни лик свештеник/свештенство има превласт над ликовима са псеудорефлексом.

3. Псеудорефлекс ије умјесто етимолошког $u$

3.1. Псеудорефлекс ије интерферира са вокалом $u$ у творби несвршених глагола који се мијењају по петој Стевановићеој врсти, а у прегледаном корпусу су потврђени глаголи покријевати/закријевати, прежијевати и кукуријекати, односно од овог посљедњег изведена именица кукуријекаюе:

(15) Да не покријеваш што с тијем дизањем? (Лопичић: 94); Виђи, виђи, пашче једно, како се закријева (Лопичић: 336);

[...] немам живаца да прежијевам по цио дан књижурине и новине (Лалић ПС: 108); 
Тек што пијетао закукуријека [...] (Лопичић: 439); [...] удари у кукуријекање (Вуковић: 64).

Већина дијалектолошких студија 5 биљежи итеративне глаголе покријевати и сакријевати. Интерференцију uje : $u$ у овом и сличним случајевима (нпр. тијевати) тумачимо односом према презентској основи свршеног глагола (лити : лијем, крити : кријем), из које је нејатовска секвенца ије пренесена и на несвршени глагол.

С друге стране, несвршени глагол прежијевати не биљежи ниједан опис народних говора, док је појава ономатопејског глагола кукуријекати посвједочена у свим описаним говорима, осим пљеваљског (в. Јовановић 20056: 348).

3.2. Псеудорефлекс ије јавља се умјесто нормативног $u$ или напоредо са њим и у ријечима страног поријекла које на том мјесту имају дифтонг са компонентом $u$ на првом мјесту, или пак вокале $u$, односно $e$. Све те ријечи су у народне говоре у Црној Гори ушле као псеудоијекавизми, а неке је, због њихове распрострањености прихватила и норма (нпр. талијер поред талир, панцијер поред панцир).

3.2.1. Грађа коју даље наводимо припада говору ликова, тј. туђем говору. У том погледу су посебно илустративни примјери забиљежени у Команиновом дјелу:

(16) Ја мислим да је дјед Тиодор добио то мјесто за вјечну кућу зато што је био официчр и командир пелиновачког батаљона [...] Баба Јегда је говорила: командијер и официјер! (Команин: 95); У свом сам дјетињству вјеровао у мртваце који ноћу устају из гробова То су вампири. А Пелиновљани кажу: „Вампијери!” (Исто: 74).

Лексеме командијер и обицијер забиљежене су и код Лопичића, док је глагол упанцијерити (постати као

5 Уп: Стевановић 1933/1934: 27; Вушовић 1927: 10; Милетић 1940: 252; Јовановић 2005a: 117. 
панцир) пронађен у језику једног од старијих црногорских писаца:

(16а) Соколе нас офиичјери (Лопичић; 379); Предаде је командијеру (Лопичић: 381); [...] скочи командијер (Исто: 381); [...] ланена се кошуља упанцијерила (Иванишевић, Извиријеч; 139).

Наведене лексеме представљају латинизме или италијанизме, а умјесто секвенце ије, у изворном облику имају дифтонг ie у склопу веома продуктивног суфикса -iere. Овај суфикс је, према ријечима Д. Вушовића (1927: 10), у народним говорима ${ }^{6}$ истиснуо суфикс -uр, који има мању продуктивност. То је и разлог што се секвенца ије развила и у ријечима усвојеним не само из италијанског него и из других језика. Тако су се у језику црногорских писаца нашле из народних говора пренесени грцизам путијер и германизам талијер:

(17) [...] није се могло у нас без [...] путијера (Јововић, Извиријеч: 114);

(18) [...] сто талијера да ти дарује (Јововић, Извиpujeч: 119).

У РМС су забиљежени, поред регуларних, и ови облици, с тим што се за путијер наводи да је покрајинска ријеч (РМС 5: 305), а за талијер се каже да је у питању ијекавизам (РМС 6: 135). Међутим, у РјЈАЗУ уз ријеч талијер стоји да је постала од њемачког taler уз напомену да је то једна од ријечи у којима долази ије умјесто изворног е или $и$ (РјЈАЗУ 18: 42) .

3.2.2. У језику старијег црногорског приповједача Луке Јововића забиљежен је псеудорефлекс ије умјесто општеприхваћеног и у глаголу (из)лишити:

(19) [...] узео бјех [прћију] оној најстаријој, па оне

6 Сви дијалектолошки описи црногорских народних говора свједоче о присуству ових лексема - в. Вушовић 1927: 9-10; Стевановић 1933-1934: 27; Вуковић 1938-1939: 17; Милетић 1940: 254; Пешикан 1965: 105; Станић 1974: 75; Ћупић 1977: 29; Пижурица 1981: 73; Јовановић 2005а: 116; Бојовић 2009: 76. 
друге да не излијешим и не искобим (Јововић, Извирuјеч: 126).

Овај глагол је усвојен из латинског језика (лат. lisciare), с тим што му је, очигледно, народно језичко осјећање додијелило секвенцу ије умјесто изворног $u$.

3.2.3. Исту ситуацију показује однос општеприхваћеног германизма ииль према спорадичној употреби лика иијељ, забиљеженог у језику Николе Првог Петровића.

(20) [...] кад прегне човјек жив да гине / за род и вјеру, за иијељ свету/ [...] бог ће му сами у помоћ бити (Краљ Никола: 542).

Ријеч ииљ је, према тумачењу у РјJАЗУ (4: 795), настала од њемачког ziel, па је овдје и изворни облик погодовао за развијање псеудоијекавизма.

3.4. Иако је норма, због њихове распрострањености, прихватила неке од наведених псеудоијекавизама - лијевати, кукуријекати; талијер, паниијер - у црногорској штампи су, судећи према налазима дневника Buјести, у употреби једино ликови са вокалом $u$.

4. Псеудорефлекс је умјесто изворног $u$

Једносложни псеудорефлекс јата може се јавити на мјесту изворног кратког $u$. Биљежимо један примјер те врсте у прегледаном корпусу. У питању је лексема кандило, чије поријекло П. Скок тумачи двојако - као

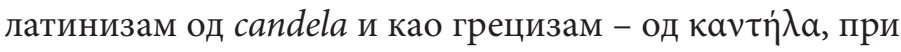
чему ликове са $e$ или чак са је аутор доводи у везу са латинским извором (Скок I: 33).

Ова ријеч је посвједочена у оба лика - као канђело и као кандило - у језику Николе Лопичића:

(20а) Ни уље у канђела не би оставили (Лопичић; 31); [...] кријемо је Богом, иконом и канђелом (Исто: 403); нема канђела (Исто: 403);

(20б) Годинама му је палила кандила (Лопичић; 129). 
Двојаки ликове ове именице посвједочени су у опису црмничког говора (Милетић 1940: 253), док их друге студије не помињу, па чак ни она Пешиканова, која је најближа говорима овог писца.

Како је и очекивано, на порталу Вијести забиљежен је само нормативни облик.

5. У овом раду је анализирано укупно двадесет пет различитих ријечи које садрже неки од псеудорефлекса jama. Више од половине тих ријечи (укупно четрнаест) припада домаћем лексичком слоју, док је једанаест преузето из страних језика, при чему предњаче латинизми, односно италијанизми (осам лексема).

На основу наведене грађе закључујемо да се секундарни рефлекси јата у домаћој лексици развијају прије на мјесту кратког и дугог $e$ (однос је $7: 4$ у корист једносложног рефлекса) него умјесто вокала $u$ (забиљежена су свега три примјера те врсте - прежијевати, покријевати и кукуријекати). С друге стране, када је у питању лексика страног поријекла, примјећује се да развоју псеудорефлекса јата посебно погодују лексеме које у стандардном језику имају на том мјесту $u$ (девет од једанаест усвојених ријечи), а у изворном облику дифтонг (таквих је шест). Само у двјема ријечима (подумијента и сјекирати се) двосложни, односно једносложни рефлекс мијења изворно страно $e$. 


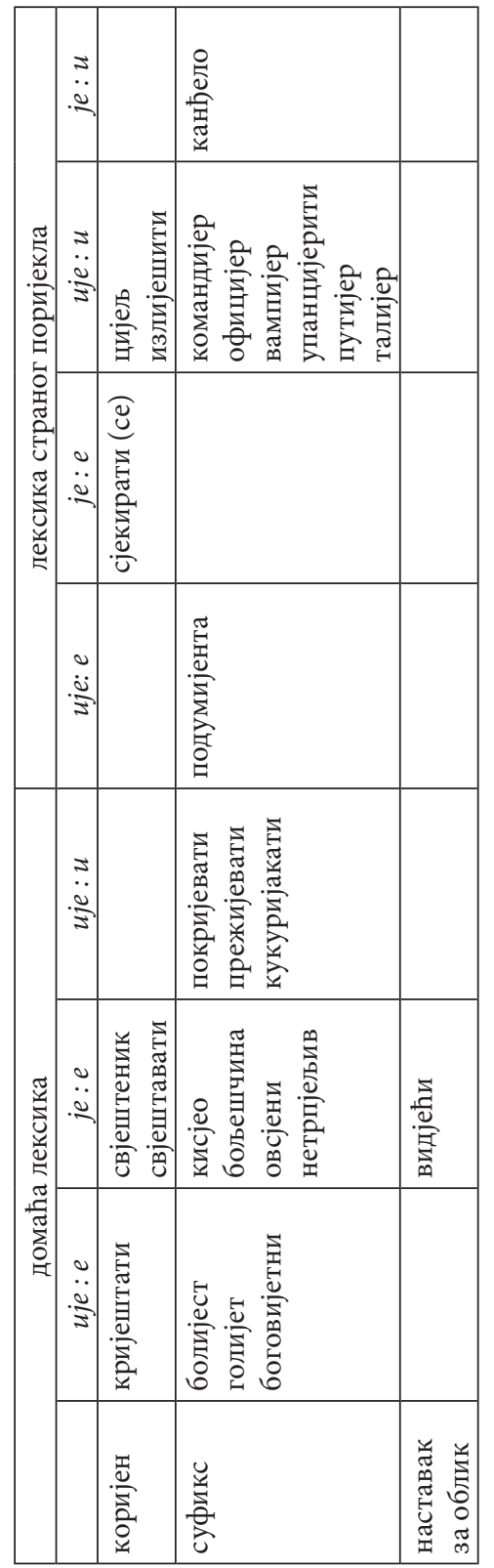


5.1. Од наведених података много су интересантнији они који показују у којем типу морфема се развијају секундарни рефлекси јата. У десет од четрнаест домаћих ријечи са псеудорефлексом јата, ова појава захвата суфикс, у једном случају чак и наставак за облик (видјећи), а свега у три случаја је евидентирана у коријену ријечи. Сличан однос показују и стране ријечи - у три страна коријена биљежимо секундарни рефлекс јата, док се у преосталих осам ова појава развија у суфиксу.

5.2. Лингвистички су ипак најзанимљивији разлози који доводе до појаве псеудорефлекса̂ jama. У досадашњим истраживањима псеудојатизам се доводи у везу са паронимском атракцијом или, другачије речено, народном етимологијом (Шипка 2010). ${ }^{7}$ И заиста то и јесте разлог употребе секундарних рефлекса у ријечима какве су вјересија, ијелулит, осјека итд, али наведени псеудоијекавизми су знатно другачији од оних које смо пронашли у језику црногорских писаца. А основна разлика лежи управо у томе што је појава, код првих, захватила коријен ријечи, па је народно језичко осјећање доводи у везу са коријеном који има сличан фонетски састав. Међутим, само мали број наших примјера се даิ објаснити као паронимска атракција (свјештеник, сјекирати се, боговијетан, прежијевати (према преживјети), можда и придјеви кисјели и овсјени. У знатном броју наших примјера посриједи је прије интерференција са ријечима које припадају истом деривационом гнијезду, а изведене су управо суфиксом који садржи регуларни јатовски рефлекс (болијест : оботијевати, болешчина: болети, нетрпјельив : трпјети, видјећu: видјети) или пак секвенцу ије која није јатовског поријекла (покријевати : покријем).

7 Појаву развијања хиперијекавизма под утицајем коријена који у себи садрже јат В. Путанец назива реетимизацијом (Путанец 1963: 79). 
Када су у питању псеудорефлекси вокала jam у лексици страног поријекла, наша анализа показује да је и фонетски, односно ортографски лик изворне ријечи са дифтонгом іе погодовао да се развије народним говорима пријемчивија варијанта са uje (comandiere : командијер : командир). Ово не искључује могућност паронимске атракције приликом усвајања ријечи из страних језика. Напротив, једино је тако могуће објаснити секвенцу је у глаголу сјекирати се (доведен је у везу са сјекиром) или у ријечи подумијента (веза са презентом глагола умјети).

Напоменимо на крају да су од анализираних двадесет пет лексема са псеудорефлексима јата у језику савремене црногорске штампе заживјеле само двије свјештеник, односно свјештенство и придјев кисјели. Притом је први псеудојекавизам неупоредиво рјеђи од нормативног лика са вокалом $e$, док је код придјева $к u$ сели ситуација још у превирању, и врло је могуће да ће у овом случају превагнути рефлекс је, тим прије што није ни сасвим извјесно да је овдје посриједи псеудојатизам.

\section{ИЗВОРИ}

Вијести: www.vijesti.me

Вуковић: С̌. Vuković, Mrtvo Duboko, Sarajevo: Svjetlost, 1963.

Ђилас: М. Ђилас, Црна Гора, Цетиње: Обод, 1994.

Извиријеч (ирногорска приповједачка проза од Његоша до

1918),прир. Ч. Вуковић, Титоград: Графички завод, 1973.

Команин: Ж. Команин, Колијевка, Цетиње: Обод, 1994.

Краљ Никола: Изабрана дјела, Цетиње: Обод, 1977.

Лалић ПС: M. Lalić, Prvi snijeg, Beograd: Nolit-Podgorica:

Pobjeda, 1979.

Лалић C: M. Lalić, Svadba, Podgorica: Biblioteka Vijesti, 2004.

Лопичић: Н. Лопичић, На камену (приповијетке), Цетиње:

Народна књига, 1953. 


\section{ЛИТЕРАТУРА}

Бојовић 2009: Д. Бојовић, Говор Потарја, рукопис докторске дисертације, Београд: Филолошки факултет.

Вуковић 1938-1939: Ј. Вуковић, Говор Пиве и Дробњака, Јужнословенски филолог, књ. XVII, 1-114.

Вушовић 1927: Д. Вушовић, Диалект источне Хериеговине, Београд: Графички завод „Макарије”.

Ђуровић 1980: Р. Ђуровић, Рефлекси јата у околини Прибоја,

СДЗб, књ. XXVI, Београд: САНУ, 235-319.

Јовановић 2005a: М. Јовановић, Говор Паштровића, Подгорица: Универзитет Црне Горе.

Јовановић 2005б: М. Јовановић, Икавска замјена јата у говорима Црне Горе, Српски језик, X/2, Београд, 333-349.

Маројевић 2005: Р. Маројевић, Текстологија Горског вијенца,

y: Петар II Петровић Његош, Горски вијенаи, критичко издање, Подгорица: ЦИД, 227-1000.

Милетић 1940: Б. Милетић, Црмнички говор, СДЗб IX, Београд: Српска краљевска академија.

Остојић 2003: Б. Остојић, Рефлекси јата у језерско-шаранском говору, О ирногорском книжевнојезичком изразу, Подгорица: Универзитет Црне Горе, 253-266.

Пецо 1967: А. Пецо, Јекавски облик једнога прилога, Наш језик. књ. XVI, св. 1-2, 93-96.

Пешикан 1965: М. Пешикан, Староцрногорски средњекатунски и љешански говори, СДЗб, књ. XV, Београд: Институт за српскохрватски језик.

Пижурица 1981: М. Пижурица, Говор околине Колашина, Подгорица: ЦАНУ.

Правопис 2014: Правопис српскога језика, Нови Сад: Матица српска.

Путанец 1963: V. Putanec, Neki noviji hiperjekavizmi, Jezik, br.

3, Zagreb: Hrvatsko filološko društvo, 75-79.

PjJA3Y: Rječnik hrvatskoga ili srpskoga jezika, Zagreb: Jugoslavenska akademija znanosti i umjetnosti, I-XXIII, 1880-1976.

PMC: Речник српскохрватскога книжевног језика, Нови Сад: Матица српска - Загреб: Матица хрватска, књ. I-VI, 1967-1976. 
Стевановић 1933-1934: М. Стевановић, Источноцрногорски дијалекат, Јужнословенски филолог, књ. XIII, 1-128.

Стевановић 1953: М. Стевановић, Неки „спорни” јекавизми, Стварағе, бр. 3, год. VIII, Титоград, 108-119.

Станић 1974: М. Станић, Ускочки говор I, СДЗб, књ. ХХ, Београд: Институт за српскохрватски језик.

Ћупић 1977: Д. Ћупић, Говор Бјелопавлића, СДЗб, књ. XXIII, Београд: Институт за српскохрватски језик.

Шипка 2010: М. Шипка, Псеудојатизам и стандарднојезичка норма, у: (ур. М. Ковачевић) Интердисииплинарност и јединство савремене науке, Пале: Филозофски факултет, 169-182.

Анна Янюшевич Оливери

\section{ПСЕВДОРЕФЛЕКС ЯТЯ В ЯЗЫКЕ ПИСАТЕЛЕЙ ЧЕРНОГОРИИ}

\section{PЕЗЮМЕ}

Предметом данной работы являются слова и формы слов, в которых вместо этимологических $u$ или $e$ появляется псевдорефлекс „ять“ (ије или је). Исследование, охватившее двадцать пять слов, показало, что вторичные рефлексы „ятя“ в сербской лексике развиваются на месте краткого или долгого $е$ вместо вокала $u$, тогда как в словах иностранного происхождения развитию псевдорефлекса способствуют лексемы, в литературном языке в данном положении имеющие $u$, а в исконной форме дифтонг. Проведенный анализ указывает на вторичность рефлексов „ятя“, прежде всего обнаруживающихся в суффиксальных морфемах, причем их появление, в большинстве случаев, обусловлено интерференцией со словами одинакового словообразовательного гнезда, производными с суффиксом регулярного рефлекса „ятя“.

Ключевые слова: псевдорефлекс, вокал „ять“, је-рефлекс, ије-рефлекс, корень, суффикс. 